\title{
ガスクロマトグラフィーによる不飽和脂肪酸の光化学変化の研究
}

\section{Studies on Photochemical Changes in Unsaturated Fatty Acids by Gas Chromatography.}

前報*1 に持いてオレイン酸メチルオゾニド挍よびリノール酸メチルオゾニドを直接ガスクロマトグラフィーに かけオゾニドを定量し，また分解生成物 methyl aldehydoazelate (a), 1-decanal (b), capronaldehyde (c) な どのピークを同定した.そしてこれらの結果から不飽和酸エステル拉よびそれのオゾニドの安定性, 分解などに 関し二, 三の知見を得たが，著者はこの方法を用いて不飽和脂肪酸のらちオレイン酸メチル*2, リノール酸メチ ル*3, リノレン酸メチル*4 について酸素が存在する場合の日光和よび紫外線照射の影響を検討した。その結果 二, 三の興味ある事実が分かつた。 MOS, MLS, MLnS を直射日光にあてた場合の変化のガスクロマトグラフ イーに現われるピークはいずれもそれぞれのオゾニドの場合と同一で明瞭に現われる. 一例として MLS $150 \mathrm{mg}$ を照射面積約 $2 \mathrm{~cm}^{2} て ゙ 4$ 時間直射日光にあてた場合のガスクロマトグラムをFig. 1 に示すが，この条件で MLS の $1 / 2$ 以上が変化を受けて拈りこの変化は酸素が存在しなければ起こらない。つぎに化学変化を起こす光の波長

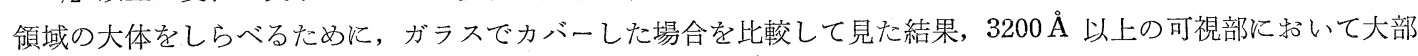
分の変化を起こすことが分かつた。 また同一条件に扣いて MOS, MLS, MLnS について 2, 4, 6, 8, 10 時間日 光にあてた場合の変化速度をガスクロマトグラフィーに現われるピーク面積から比較した結果, 拉よそ $1: 4: 9$ になることが分かり，このことから不飽和脂肪酸の光化学変化速度は二重結合の数の二乗に比例するものと考兄 られる.

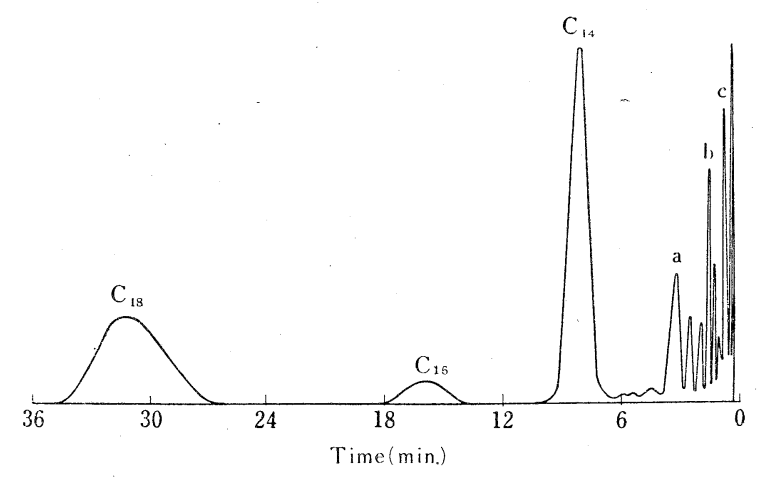

Fig. 1. Recorder Tracings from Gas Chromatography

Condition : M.L.S., $150 \mathrm{mg}$. in ca. $2 \mathrm{~cm}^{2}$. of surface was exposed to direct sunlight for $4 \mathrm{hr}$. Column length $2 \mathrm{~m}$., DM-14 A, Silicone grease

Helium flow-rate $60 \mathrm{cc} . / \mathrm{min}$., Temp. $226^{\circ}$.

Pharmaceutical Faculty,

University of Kumamoto.

Kuhonji, Ôe-machi, Kumamoto.

北原 一 太

(Kazuta Kitahara)

*1 第 1 報, 第 2 報 : 本誌 80, 1624, 1628(1960).

*2 オレイン酸メチル測定標準物 (MOS) で内部標準物質としてミリスチン酸メチルを混合したもの.

*3 リノール酸メチル測定標準物 (MLS).

*4リノーレン酸メチル測定標準物 $(\mathrm{MLnS})$. 